\title{
Bentazon mixtures to control weeds in rice'
}

\author{
Li C. Liu and Jose J. M. Lozano
}

\begin{abstract}
Three herbicide trials on rice (Oryza sativa L.) were conducted on Coloso clay (Entisols) and on Toa clay loam (Mollisols) from 1981 to 1983 with bentazon [3(1-methyl)-(1 H)-2,1,3-benzothiadiazin-4-(3H)-one 2,2dioxide] mixed with propanil [N-(3,4-dichlorophenyl) propanamide] or with bifenox [methyl 5-(2,4-dichlorophenoxy) 2-nitrobenzoate] for early postemergence weed control. Good to excellent weed control was obtained by the above-mentioned bentazon mixtures. These mixtures were particularly effective against rice flatsedge (Cyperus iria L.), a weed not previously controlled by other herbicides. Marginal herbicide phytotoxicity to rice plants was noted in one trial when bentazon at a higher rate was mixed with propanil. All bentazon mixtures resulted in higher yields than standard treatment of propanil alone or thiobencarb [S-(4-dichlorophenyl methyl diethylcarbamothioate] alone by a margin of 8.7 to $26.9 \%$.
\end{abstract}

\section{INTRODUCTION}

Several species of the sedge family (Cyperaceae) have become pernicious weeds infesting rice fields in different hemispheres $(2,3,6,7)$. In Puerto Rico, González-Más (4) identified 111 species of Cyperaceae from 2,700 locally collected specimens. Among them, purple nutsedge (Cyperus rotundus L.), yellow nutsedge (C. esculentus L.), and rice flatsedge $(C$. iria L.) are the most abundant sedges in our rice fields. Since the first two species of sedge are partially controlled by propanil or 2,4-D application, weed population has shifted to the predominating rice flatsedge, which is not controlled with the two above-mentioned herbicides. Bentazon has been reported to be effective against a number of broadleaf and sedge weeds $(1,8)$. Three field trials were initiated from 1981 to 1983 to evaluate the use of bentazon mixtures for sedge control in rice fields in Puerto Rico. This paper summarizes research findings on the efficacy and phytotoxicity of bentazon mixtures for weed control in rice. The grain yield as affected by different bentazon mixtures is also presented.

\section{MATERIALS AND METHODS}

\section{Herbicide Experiment No. 1}

This experiment was established on a Coloso clay (Fluvaquents, fine, mixed, nonacid, isohyperthermic) at the Gurabo Substation located in

${ }^{1}$ Manuscript submitted to Editorial Board May 14, 1986.

${ }^{2}$ Phytophysiologist; and Assistant Researcher, Agricultural Experimment Station, Mayagüez Campus, University of Puerto Rico, Rfo Piedras, P. R. 00928. 
the north central part of Puerto Rico. The rice cultivar Brazo was seeded June 10,1981 . Thiobencarb at $4.48 \mathrm{~kg}$ ai/ha was applied preemergent June 11, 1981. Postemergence bentazon at either 2.1 or $4.2 \mathrm{~kg}$ ai/ha in combination with propanil at $3.36 \mathrm{~kg}$ ai/ha and thiobencarb at $4.48 \mathrm{~kg}$. ai/ha was applied June 22, 1981, when jungle rice reached 2- to 3-leaf stage. The herbicide spray was applied with a portable $\mathrm{CO}_{2}$ sprayer fitted with an 8001 nozzle tip. The spray volume was $187 \mathrm{~L} /$ ha at a pressure of $2.7 \mathrm{~kg} / \mathrm{cm}^{2}$. The experimental design was a randomized complete block with four replications similar to that of a previous experiment conducted by Liu et al. (5). Plots were $3.1 \times 3.1 \mathrm{~m}$. The experiment was started with dry-seeded rice, later permanently flooded soon after postemergence herbicide application. Diazinon at the rate of $3.3 \mathrm{ml}$ per liter of water was applied July 14, 1981, as a preventive measure for fall armyworm. A mixed spray of malathion and benomyl at $4 \mathrm{ml}$ and $4 \mathrm{~g}$ per liter of water in sufficient quantity was applied 2 weeks afterwards. The fertilization practice included two applications of 10-5-15 (N-P-K) at the rate of $488 \mathrm{~kg} / \mathrm{ha}$ each June 6,1981 , and July 31,1981 , respectively. One application of zine sulfate at $122 \mathrm{~kg} / \mathrm{ha}$ rate was included in the first fertilization. The check plots were hand weeded July 7, August 10 and August 31, 1981. Weed control was rated and phytotoxicity was evaluated July 23,1981 . The plants at milk stage were protected from bird damage by large plastic nets. Rice was harvested October 1, 1981, and threshed mechanically. The grains were dried to 12 to $14 \%$ of moisture. The final yield of rice was converted on the basis of $12.5 \%$ moisture content.

\section{Herbicide Experiment No. 2}

This experiment was established at the same site as herbicide experiment no. 1 with the same experimental design and plot size. Rice cultivar Mars was seeded Jan. 25, 1983. Preemergence applications of bifenox at 2.24 and $4.48 \mathrm{~kg}$ ai/ha and thiobencarb at $4.48 \mathrm{~kg}$ ai $/ \mathrm{ha}$ were made the day after planting. Postemergence applications of bentazon at 2.77 and $5.54 \mathrm{~kg}$ ai/ha were made March 10, 1983. The first fertilizer was incorporated into the soil at the time of planting. Fertilizer 15-5-10 was applied at $454 \mathrm{~g}$ per plots. The second application included the same formulation at $227 \mathrm{~g}$ per plot 4 weeeks later. The third application, at $454 \mathrm{~g}$ per plot, was made March 27, 1983. The fourth application was limited to ammonium sulfate at $0.5 \mathrm{~kg}$ per plot. Pesticide management included a mixture of benomyl+malathion $/ 1.12 \mathrm{~kg}$ ai $/ \mathrm{ha}+2.34 \mathrm{~L} / \mathrm{ha}$ ) immediately before the flowering stage. Malathion at the same rate was applied a second time for insect control. The check plots were hand weeded three times at approximately monthly intervals. Weed control and phytotoxicity ratings were made March 21, 1983. A plastic net was extended over 
the rice plants at milk stage to prevent bird damage. Rice was harvested May 23, 1983.

\section{Herbicide Experiment No. 3}

This experiment was established on a Toa clay loam (Fluventic, Hapludolls, fine, mixed, isohyperthermic) located in Vega Baja, Puerto Rico. Rice cultivar Mars was planted in a privately owned commercial field. The total area included in the test was 14 acres. The seeds were broadcast at the rate of $136 \mathrm{~kg} / \mathrm{ha}$ by airplane May 20, 1983. The field was prepared under flood conclition. Herbicide treatments including propanil at $3.36 \mathrm{~kg}$ ai $/ \mathrm{ha}$, propanil + bentazon $(3.36 \mathrm{~kg}$ ai/ha $+2.1 \mathrm{~kg}$ ai/ha) were applied June 4, 1983, from an airplane at a spray volume of $93.5 \mathrm{~L} / \mathrm{ha}$ as an early postemergent. Urea was applied July 8, 1983, at a rate of 146 $\mathrm{kg} /$ ha. Potassium fertilizer was applied a second time 3 weeks later. No insecticide or fungicide was used during the course of this experiment. Weed control ratings and phytotoxicity evaluations were made June 30 , 1983. The rice plants were harvested at random, 7 samplings per treatment, Sept. 11, 1983. The area sampled for harvest was $2.4 \times 2.4 \mathrm{~m}$. The harvested grains were dried in a low-temperature oven to a moisture content of $12.5 \%$.

\section{RESULTS}

Herbicide Experiment No. 1

Jungle rice, Echinochloa colonum (L.) Link., and rice flatsedge (Cyperus iria L.) were two predominant weeds present in the experimental area. The minor weed species included wild bush bean (Macroptilium lathyroides L.), purslane (Portulaca oleracea L.), niruri (Phyllanthus niruri L.), eclipta [Eclipta alba (L.) Hassk.], goose grass (Eleusine indica (L.) Gaertn.], spreading dayflower (Commelina diffusa Burn. f.), Mexican weed [Caperonia palustris (L.) St. Hil.], mornig glory [Ipomoea tiliacea (Willd.) Choisy], red tasselflower [Emilia sonchifolia (L.) DC.], crabgrass [Digitaria sanguinalis (L.) Scop.], waterprimrose [Ludwigia erecta (L.) H. Hara], and finger (Chloris inflata Link.). Excellent control of grasses and sedges was achieved by bentazon mixtures at either 2.1 or $4.2 \mathrm{~kg}$ ai/ha with propanil at $3.36 \mathrm{~kg}$ ai/ha (table 1 ). Thiobencarb at $4.48 \mathrm{~kg}$ ai/ha applied alone either as preemergent or early postemergent also gave good grass control, but provided no sedge control. Propanil alone at $3.36 \mathrm{~kg} \mathrm{ai} /$ ha gave good grass control, but sedge control was not as good as that with bentazon mixtures.

No rice plant injury was noted when bentazon at $2.1 \mathrm{~kg}$ ai/ha was mixed with propanil at $3.36 \mathrm{~kg}$ ai/ha. Slight stand reduction of rice plants was suspected when bentazon at $4.2 \mathrm{~kg}$ ai/ha was mixed with propanil at $3.36 \mathrm{~kg}$ ai/ha. Thiobencarb at $4.48 \mathrm{~kg}$ ai/ha applied either preemergent 
TABLE 1.-Effect of different herbicide treatments on weed control, phytotoxicity and yield of vice at the Gurabo Substation.

\begin{tabular}{|c|c|c|c|c|c|}
\hline \multirow{2}{*}{ Herbicide treatments } & \multicolumn{3}{|c|}{ Weed control $^{1}$} & \multirow{2}{*}{$\begin{array}{l}\text { Phyto- } \\
\text { toxicity" }\end{array}$} & \multirow[b]{2}{*}{ Grain yield $^{3}$} \\
\hline & Grasses & Broadleaves & Sedges & & \\
\hline & & & & & $k g / h a$ \\
\hline Propanil $3.36 \mathrm{~kg}$ ai/ha (post) & 84 & 70 & 45 & 0 & $4,236 \mathrm{a}$ \\
\hline \multicolumn{6}{|l|}{ Bentazon $2.1 \mathrm{~kg}$ ai/ha +} \\
\hline propanil $3.36 \mathrm{~kg}$ ai/ha (post) & 90 & 75 & 78 & 0 & $5,138 \mathrm{a}$ \\
\hline \multicolumn{6}{|l|}{ Bentazon $4.2 \mathrm{~kg} \mathrm{ai} / \mathrm{ha}+$} \\
\hline propanil $3.36 \mathrm{~kg}$ ai/ha & 87 & 79 & 85 & 10 & $3,932 \mathrm{a}$ \\
\hline Thiobencarb $4.48 \mathrm{~kg}$ ai/ha (pre) & 84 & 51 & 0 & 0 & $4,500 \mathrm{a}$ \\
\hline Thiobencarb $4.48 \mathrm{~kg}$ ai/ha (post) & 80 & 40 & 0 & 0 & $4,135 \mathrm{a}$ \\
\hline Weeded check & 94 & 95 & 90 & 0 & $5,059 \mathrm{a}$ \\
\hline Nonweeded check & 0 & 0 & 0 & 0 & $1,978 \mathrm{~b}$ \\
\hline
\end{tabular}

${ }^{1}$ Weed control ratings are based on a scale of 0 to 100 , where $0=$ no control, $100=$ complete control.

${ }^{2}$ Phytotoxicity evaluations are based on a scale of 0 to 100 , where $0=$ no crop injury, $100=$ complete stand reduction.

${ }^{3} \mathrm{Gr}$ rin yield is an average of four replications. Values in the column followed by the same letter do not differ statistically at $\mathrm{P}=0.05$.

or early postemergent caused no rice injury. Neither did propanil at 3.36 $\mathrm{kg}$ ai/ha applied as early post emergent cause any crop injury.

There were no significant differences in yield among different herbicide treatments with the exception of the unweeded check. The highest grain yield was obtained with bentazon at $2.1 \mathrm{~kg}$ ai $/ \mathrm{ha}+$ propanil at 3.36 $\mathrm{kg}$ ai/ha. The lowest grain yield was obtained in the nonweeded check as expected.

TABLE 2.-Effect of different herbicide treatments on weed control, phytotoxicity and yield of rice at the Gurabo Substation

\begin{tabular}{|c|c|c|c|c|c|}
\hline \multirow{2}{*}{ Herbicide treatments } & \multicolumn{3}{|c|}{ Weed control ${ }^{\mathrm{I}}$} & \multirow{2}{*}{$\begin{array}{l}\text { Phyto- } \\
\text { toxicity }\end{array}$} & \multirow[b]{2}{*}{ Grain yield ${ }^{3}$} \\
\hline & Grasses & Broadleaves & Sedges & & \\
\hline & & & & & $k g / h a$ \\
\hline Bentazon $2.77 \mathrm{~kg} \mathrm{ai} / \mathrm{ha}$ (post) & 93 & 80 & 85 & 0 & $3,250 \mathrm{~b}$ \\
\hline Bentazon $5.54 \mathrm{~kg}$ ai/ha (post) & 96 & 85 & 92 & 0 & $3,677 \mathrm{ab}$ \\
\hline Thiobencarb $4.48 \mathrm{~kg}$ ai/ha (pre) & 90 & 30 & 0 & 0 & $3,164 \mathrm{~b}$ \\
\hline Weeded check & 95 & 92 & 95 & 0 & $4,297 \mathrm{a}$ \\
\hline Nonweeded check & 0 & 0 & 0 & 0 & $1,529 \mathrm{c}$ \\
\hline
\end{tabular}

${ }^{1}$ Weed control ratings are based on a scale of 0 to 100 , where $0=$ no control, $100=$ complete control.

${ }^{2}$ Phytotoxicity evaluations are based on a scale of 0 to 100 , where $0=$ no stand reduction of rice, $100=$ complete stand reduction.

${ }^{3}$ Grain yield is an average of four replications. Values in the column followed by the same letter do not differ statistically at $\mathrm{P}=0.05$.

4 This treatment was preceded by bifenox at $2.24 \mathrm{~kg} / \mathrm{ha}$ as a preemergence application.

${ }^{5}$ This treatment was preceded by bifenox at $4.48 \mathrm{~kg} / \mathrm{h}$ a as a preemergence application. 
Herbicide Experiment No. 2

Two predominant weed species encountered in this experiment included jungle rice, spurge (Euphorbia heterophylla L.), common sedge (Cyperus diffusa Vahl.), wild bush bean, sesbania [Sesbania exaltata (Raf.) Cory], goose grass, purple nutsedge (C. rotundus L.), niruri, and rice flatsedge. Bentazon at $2.77 \mathrm{~kg}$ ai/ha controlled grasses excellently (table 2). The same treatment also provided satisfactory control of broadleaved weeds and sedges. When the rate of bentazon was raised to 5.54 $\mathrm{kg}$ ai/ha, excellent control of grasses and rice flatsedge was obtained. The standard herbicide thiobencarb gave excellent control of grasses, but it was ineffective against rice flatsedge. No phytotoxicity was noticed on any of the above-mentioned herbicide treatments. The weeded check produced the highest grain yield. It was then followed by that with bentazon at $5.54 \mathrm{~kg}$ ai $/$ ha preceded by bifenox at $4.48 \mathrm{~kg}$ ai/ha as a preemmergent. The yield difference between these two treatments was nonsignificant. Bentazon at $2.77 \mathrm{~kg}$ ai/ha, preceded by bifenox at $2.28 \mathrm{~kg}$ ai/ha, ranked third in affecting yield; thiobencarb treatment was fourth at 4.48 $\mathrm{kg}$ ai/ha. The non-weeded check produced the lowest grain yield.

\section{Herbicide Experiment No. 3}

The predominant weed species encountered in the commercial rice field were jungle rice, sprangletop [Leptochloa filiformis (Lam.) Beauv.], spreading dayflower, rice flatsedge, purple nutsedge, yellow nutsedge, eclipta, purslane, waterprimrose and morning glory. Bentazon at $2.1 \mathrm{~kg}$ ai/ha + propanil at $3.36 \mathrm{~kg}$ ai/ha gave excellent control of grasses and sedges (table 3). However, propanil alone at $3.36 \mathrm{~kg}$ ai/ha effectively controlled the grasses but was ineffective against the predominating rice flatsedge. No phytotoxicity to rice plants was noted in different herbicide treatments. The highest grain yield was obtained when bentazon at 2.1 $\mathrm{kg}$ ai/ha + propanil at $3.36 \mathrm{~kg}$ ai/ha was applied. It was followed by the yield resulting from application of propanil alone at $3.36 \mathrm{~kg}$ ai/ha. The

TABLE 3.-Effect of different herbicide treatments on weed control, phytotoxicity and yield of rice in Vega Baja farm

\begin{tabular}{lccccc}
\hline \multirow{2}{*}{ Herbicide treatments } & \multicolumn{3}{c}{ Weed control $^{1}$} & $\begin{array}{c}\text { Plyto- } \\
\text { toxicity }\end{array}$ & Grain yield \\
\cline { 2 - 3 } & Grasses & Broadleaves & Sedges & & $\mathrm{kg} / \mathrm{ha}$ \\
Bentazon $2.1 \mathrm{~kg} \mathrm{ai} / \mathrm{ha}+$ & & & & & \\
$\quad$ propanil $3.36 \mathrm{~kg} / \mathrm{ha}$ (post) & 95 & 88 & 91 & 0 & 2,949 \\
Propanil $3.36 \mathrm{~kg} \mathrm{ai} / \mathrm{ha}$ & 95 & 85 & 15 & 0 & 2,155 \\
Nonweeded check & 0 & 0 & 0 & 0 & 801 \\
\hline
\end{tabular}

'Weed control ratings are based on a scale of 0 to 100 , where $0=$ no control, $100=$ complete control.

${ }^{2}$ Phytotoxicity evaluations are based on a scale of 0 to 100 , where $0=$ no stand reducton of rice, $100=$ complete stand reduction. 
non-weeded check yielded poorly. As the experiment was not replicated, no statistical analysis was performed on the yield data.

\section{DISCUSSION}

Propanil is known to control purple nutsedge, but it is ineffective against rice flatsedge. As a result, rice flatsedge has become the predominating sedge in Vega Baja rice fields. Bentazon at $2.1 \mathrm{~kg}$ ai/ha + propanil at $3.36 \mathrm{~kg}$ ai/ha gave excellent control of rice flatsedge. The registration of bentazon in Puerto Rico was granted on the basis of our field data. Bentazon in combination with propanil certainly provides the most effective tool against rice flatsedge.

The effectiveness of bentazon against rice flatsedge was first noticed in our herbicide experiment no. 1. This herbicide continued to demonstrate its superior weed control against rice flatsedge in experiment no. 2. Bentazon in combination with propanil again provided excellent control of rice flatsedge in commercial rice fields in Vega Baja as well as experiment no. 3. In view of the experimental data obtained to date, we are convinced that bentazon + propanil would give the added advantage of controling rice flatsedge and other mixed weed populations.

As to crop safety, bentazon mixtures caused only slight injury in one out of three experiments. Marginal crop injury caused by bentazon mixtures was later overcome.

In herbicide experiment no. 1 , with respect to rice yield, the treatment with bentazon at $2.1 \mathrm{~kg} / \mathrm{ha}+$ propanil at $3.36 \mathrm{~kg}$ ai/ha outyielded that with the standard treatment of propanil at $3.36 \mathrm{~kg}$ ai/ha by $17.6 \%$. Rice treatment with bentazon mixtures outyielded that with the standard herbicide thiobencarb by a margin of $8.7 \%$ in experiment no. 2 . In the third herbicide experiment, rice with bentazon + propanil mixture outyielded that with propanil alone by $26.9 \%$.

\section{RESUMEN}

\section{Mezclas de bentazon para desmalezar arrozales}

Las mezclas se aplicaron en tres experimentos de campo en los suelos Coloso arcilloso (Entisol) y marga arcillosa Toa (Mollisol) de 1981 a 1983. El herbicida bentazon se evaluó en combinación con propanil y con bifenox para combatir las malezas en arrozales. Cuando bentazon se combinó con propanil, bifenox o ambos, se logró un control exelente. Estas mezclas fueron muy efectivas contra el coquí (Cyperus iria L.), una maleza que no se había controlado anteriormente con ningún herbicida. Se observó una leve fitotoxicidad con la mezcla de bentazon y propanil en uno de los tres experimentos. Los rendimientos de arroz fueron más elevados en las parcelas tratadas con las mezelas de bentazon que con los tratamientos corrientes de propail o thiobencarb. El porcentaje de aumento en producción con las mezclas con bentazon en comparación con los herbicidas corrientes fluctuó entre 8.7 y $26.9 \%$. 


\section{LITERATURE CITED}

1. Anonymous, 1976. Basagran Technical Data Sheet. BASF Wyandotte Corporation, p. $1-6$.

2. De Datta, S. K., 1981. Principles and Practices of Rice Production. John Wiley \& Sons, New York.

3. - - 1974. Weed control in rice: Present status and future challenge, Philipp. Weed Sci. Bull. 4: 59-65.

4. González-Más, A., 1964. Cyperaceae of Puerto Rico. Ph.D. Thesis, La. State Univ. Agric. Mech. Coll., pp. 1-316.

5. Liu, L. C., L. A. Almodóvar and J. M. Lozano, 1986. Herbicide evaluation for rice. J. Agric. Univ. P. R. 70 (21): 293-97.

6. Noda, K., 1977. Integrated weed control in rice. In Integrated Control of Weed, J. D. Fryer and S. Matsunaka, Eds, Univ. of Tokyo Press, pp. 17-44.

7. Smith, R. J., W. T. Flinchum and D. E. Seaman, 1977. Weed control in U.S. rice production, Agric. Handb. 497, USDA/ARS.

8. Weed Science Society of America, Herbicide Handbook, 5th ed, WSSA, 309 West Clark St., Champaign, Illinois 61820 . 